\title{
Kekuatan Desain Motif Batik Cirebon sebagai Ruang Identitas Indikasi Geografis Indonesia
}

\author{
${ }^{1}$ Komarudin Kudiya $\mid{ }^{2}$ Saftiyaningsih Ken Atik \\ Program Studi Kriya Tekstil dan Fashion, Universitas Muhammadiyah Bandung, Bandung, Jawa \\ Barat, Indonesia \\ Email: kkudiya@ymail.com, kendjaluatik@gmail.com
}

\begin{abstract}
ABSTRAK
Dalam sejarah batik di Indonesia, sering kali kita mendengar bahwa batik diidentikan dengan budaya masyarakat Jawa. Selain itu penggunaan kain batik pada awalnya terbatas hanya pada golongan ningrat keraton dengan berbagai aturan yang melingkupinya. Namun pada perkembangannya, batik bukan lagi dimiliki oleh masyarakat Jawa, kini produk batik tradisional telah menjadi busana Indonesia yang dipakai oleh bangsa Indonesia di seluruh Nusantara dalam berbagai kesempatan. Di Jawa Barat batik telah tumbuh dan berkembang di 27 kabupaten/kota yang tersebar dari belahan timur kabupaten Cirebon hingga di ujung sebelah barat Jawa Barat yaitu kotamadya Depok. Pada tiap-tiap daerah di Jawa Barat yang menghasilkan batik terdapat potensi karakteristik dan keunggulan teknik produksi, corak dan motif yang tidak terdapat di daerah lainnya. Keunikan dan karakteristik batik Cirebon merupakan bagian dari ruang identitas bagi masyarakat Cirebon serta layak mendapatkan Indikasi Geografis guna memberikan nilai-nilai ekonomi yang berdampak pada pelestarian tradisi batik Indonesia pada umumnya. Perlindungan Indikasi Geografis (IG) merupakan hal yang sangat penting mengingat aneka desain motif batik di Jawa Barat memiliki potensi yang sangat besar yang dapat dilindungi sebagai bagian dari Indikasi Geografis (IG) yang dapat digunakan sebagai alat pemasaran dalam dunia transaksi perdagangan, dalam kancah regional, nasional bahkan internasional.
\end{abstract}

Kata kunci : Batik Cirebon, Indikasi Geografis dan Ruang Identitas

\begin{abstract}
In the history of Indonesia batik, we used to know that batik is identified with Javanese culture. In addition, the use of batik cloth is limited to the royal court with a variety of very strict rules. But in its development, batik is no longer owned by Javanese, batik has now become one of the "national clothes" of Indonesia that is used by Indonesians throughout the archipelago on various occasions. The presence of the KeratonKasepuhan, KeratonKanoman and KeratonKacirebonan in Cirebon, West Java, have contributed greatly to the development of the Cirebon batik design, and also contributed greatly to the preservation of Indonesian batik cultural traditions. West Java has 27 districts / cities that produce traditional batik, in each district / city has the strength of the characteristics and advantages of production techniques, patterns and designs / motifs of batik that are not found in other areas. The uniqueness and characteristics of Cirebon batik designs / motifs are part of the strength of the identity space for Cirebon people and deserve protection from Geographical Indications (IG) to provide economic values that have a positive impact on them in particular as well as for the preservation of Indonesian batik traditions in general. If the strength of the identity space that gave birth to Cirebon West Java batik designs / motifs succeeded in getting IG protection from the Ministry of Law and Human Rights, this potential can be used as a marketing tool especially for the Cirebon batik crafters community in the world of trade transactions, in regional, national and even international levels.
\end{abstract}

Keywords: Cirebon Batik, Geographical Indication, Identity Space 


\section{PENDAHULUAN}

\section{a. Tinjauan Batik Cirebon Jawa Barat} Dalam naskah buhun Sunda "Siksa Kandang ng Karesian" yang ditulis disekitar abad 16 menyebutkan perihal istilah batik. Ada beberapa motif batik yang pada waktu itu telah digunakan oleh sebagian masyarakat Sunda buhun. Motifmotif tersebut tidak ada ilustrasinya hanya berupa nama, diantaranya adalah motif alas-alasan, kekembangan, hihinggulan, pasi-pasi, segeji, kembang terate dan lainnya. Sangat disayangkan bahwa kebudayaan Sunda ini tidak meninggalkan artefak berupa bentuk bangunan kerajaan yang bisa dipelajari hingga saat ini.(Setiawan, 2010).

Tokoh batik nasional Iwan Tirta dalam salah satu bukunya menyampaikan bahwa peradaban manusia selaluberkembang, dan satu diantara perkembangan yang dilakukan oleh sekelompok manusia adalah membuat bahan pakaian. Bahan yang digunakan untuk membuat pakaian tergantung dari teknologi dan bahan-bahan baku yang tersedia dilingkungan dan dimasa tersebut. Selanjutnya, ketika kemampuan manusia berkembang dan mampu membuat benang, maka akhirnya kain-kain yang digunakan untuk bahan pakaian menggunakan benang yang dipintal.(Kuhr, 2012).Dalam Kamus Besar Bahasa Indonesia,pengertian batik merupakan kain yang memilikibentuk gambar yang prosesnya dibuat khusus dengan menggoreskan atau menerakan malam/lilin panas pada kain, kemudian diproses dengan cara tertentu, hal tersebut kemudian dikenal dengan istilah kain batik.(Poerwadarminta, 2005).

Penjelasan di dalam buku batik Indonesia Indah jilid 8(1997) menyebutkan asal-usul kata batik berasal dari bahasa Jawa. Kebiasaan orang jawa dalam menyebut kata "amba" yang berarti luas atau lebar. Sementara kata "tik" berasal dari kata dasar titik yang berupa bentuk ornamen dasar dari bidang garis. Bila digabungkan kedua kata tersebut menjadi istilah batik yang memiliki makna menghubungkan beberapa titikmenjadi gambar tertentu pada kain yang luas atau lebar membentuk motif. Berdasarkan asal-usul kata tersebut, istilah "batik" kini menjelma sebagai warisan tradisi bangsa Indonesia yang tersebar diseluruh penjuru wilayah nusantara.(Yan \& Sunarya, 2010).

Penulis buku batik lainnya menyampaikan batik merupakan suatu cara khusus untuk memberi hiasan atau motif tertentu pada lembaran kain dengan cara menutupi bagian-bagian tertentu dengan menggunakan perintang berupa lilin panas. Selanjutnya dilakukan pewarnaan dengan menggunakan zat pewarna alam atau pewarna sintetis. Setelah proses pemberian warna selanjutnya kain dilorod dengan mrenggunakan air panas. (Suyani, 2013).

Berdasarkan wawancara penulis yang dilakukan dengan Sultan Sepuh XIV PRA. H. Arief Natadiningrat SE(2012), menyampaikan bahwa pembuatan kerajinan batik sudah ada sejak jaman pangeran Cakrabuwana namun tidak disebutkan tahun yang tepat dikarenakan tidak ada bukti tulisan atau naskah, namun beliau bisa menunjukkan batik-batik kuno koleksi peninggalan dari Sunan Gunung Jati yang diperkirakan sudah ada sejak abad $15 \mathrm{M}$. Batik Cirebon memiliki kelompok produksi yang terbagi menjadi a) Batik Keraton, b) Batik Pesisir dan c) Batik Ciwaringin.Sumber inspirasi dari batik Keraton Cirebon diantaranya adalah (1) Kereta-kereta kencana seperti Kereta Singa Barong, Kereta Jempana, dan Kereta Paksinaga Liman; (2) Ornamen ukiran yang terdapat pada pintu, hiasan, ukir kayu dan ukir batu; (3) Bangunan (landscaping) Taman Dalem Agung Pakungwati, Taman Air Gua Sunyaragi, Astana Gunung Jati, beserta benda-benda yang terdapat di dalamnya; (4) Keramik-keramik yang dibawa oleh pendatang dari China; serta (5) Wayang Golek Cepak dan Wayang Kulit Cirebon. (Kudiya, 2012).

Di dalam Kudiya (2014), budayawan Keraton Kanoman Cirebon yaitu Bambang Irianto berpendapat bahwa pada batik Cirebon terdapat ungkapan yang sangat indah dan tidak didapatkan dalam istilah taradisi batik dimanapaun. Karena batik 
Cirebon terlahir sebagian besar dari kaum Petarekan (para pengikut tarekat di Cirebon) memberikan istilah batik berbeda dengan pendapat dari sebagian masyarakat umum lainnya. Kata batik lebih didekatkan dengan huruf awal kata "Bismillahirrahmaanirrahim". Kata bismilah di awali dengan huruf "ba. Huruf 'ba' (huruf kedua hijaiyah, Arab) mempunyai titik pada bagian bawahnya, serta memiliki makna berbahagialah bagi orang yang memiliki sifat rendah hati. Istilah batik juga dimaksudkan sebagai sarana untuk melahirkan "suatu ikatan semangat atau cita-cita tertentu, yang diwakili sebagai bentuk risalah atau wejangan bagi generasi penerus sehingga apa yang telah ditetapkan oleh para leluhur tidak pudar. (Kudiya et al., 2014).

Lebih lanjut di dalam Kudiya (2014), budayawan Keraton Kanoman Cirebon yaitu Bambang Irianto berpendapatbahwa kaum Petarekan menyebutkan bahwa istilah 'batik', bila kata tersebut dibalik menjadi kata 'kitab'. Terlepas dari istilah utak-atik gatuk dalam bahasa Jawa, yang bisa diartikan sebagai sebuah kata yang dipaksakan memiliki keterkaitan atau ikatan. Kitab seperti yang kita ketahui bersama memiliki arti berupa sekumpulan teks yang banyak memiliki makna dan juga bisa berisi pedoman hidup manusia yang kemungkinan besar dijadikan rujukan pula bagi generasi setelahnya. Dalam, lembaran kain batik terkadang ditemukan sebuah makna filosofi luhur tentang ajaran kehidupan manusia, atau ungkapan harapan dan do'a, sebagaimana layaknya pada sebuah kitab.Keunggulan dan pengalaman yang dimiliki oleh masyarakat Cirebon Jawa Barat melahirkan teknik membatik "merawit" yang tidak dimiliki oleh daerah penghasil batik tradisional dimanapun, bukan saja di daerah penghasil batik yang berada diwilayah Jawa Barat bahkan hampir di seluruh pelosok nusantara. Teknik yang menghasilkan goresan garis kecil, tipis tanpa putus dengan latar kain berwarna muda/terang, sementara garis (outline) berwarna tua/gelap, teknik ini disebut dengan merawit. Teknik semacam ini hanya dimiliki oleh perajin batik yang berada di kawasan daerah Trusmi Plered Cirebon, tepatnya berada di desa Gamel,
Wotgali dan desa Kaliwulu Kecamatan Plered Kabupaten Cirebon Jawa Barat. Ciri khas dari pembatik Cirebon adalah mampu membuat goresan garis (wit) yang begitu tipis dan tegas (merawit)(Kudiya, 2018: 170).

\section{b. Potensi Desain Motif Batik Cirebon dan Indikasi Geografis}

Di dalam Kudiya (2016), karya disertasi tentang batik Cirebon disebutkan bahwa potensi batik Cirebon khususnya batik keraton-keraton Cirebon dengan teknik merawitnya memiliki peluang yang cukup besar untuk didaftarkan IG-nya. Motifmotif batik keraton Cirebon tersebut terbagi menjadi beberapa kelompok didasarkan pada pengelompokan yang memiliki makna Simbolik, makna Spiritual dan Makna Mitos : (a) Makna Simbolik : Patran Kembang, Patran Keris, Lenggang Kangkung, Dalungan, Simbar Kendo, Simbar Dalung, Simbar Menjangan, Keblekan, Daun Kluwih, Daun Waru, Oyod Mingmang, Sumping Darawati, Sumping Kresna Galaran, Taman Arum Kasepuhan, Taman Sunyaragi, Taman Alas Gunung Jati, Rajeg Wesi, Wadas Gerompol, Wadas Mantingan, Panji Semirang, Sawat Penganten, Sawat Romo, Sawat Riwe (teladan), Sawat Gunting, Balongan, Banjar Balong. (b) Simbol Mitologi, seperti : Paksi Naga Liman, Singa Barong, Naga Seba, Singa Payung, Naga Utah-utahan, Sawung Galing, Bouroq, Wadas Singa (Kanoman), Urang Supit, Ceplok Bintulu, Singa Kanoman, Singa Banaspati dan Sawat Gledek. (c) Makna Spiritual, seperti : Patran Kangkung, Masjid Trusmi, Taman Teratai, Taman Arum Pakungwati, Siti Inggil Kanoman, Insan Kamil, Gunung Giwur, Gedongan Sunyaragi, Lawang Gada, Gapura (Gofuran), Gedongan Sunyaragi, Puser Bumi dan Keprabonan. Beberapa desain motif batik Cirebon khususnya batik Keraton Kasepuhan dan batik Keraton Kanoman Cirebon yang memiliki potensi untuk mendapatkan IGnya, seperti yang tercantum pada gambar 1(Gbr.1), diantaranya motif batik Taman Teratai (A), motif batik Paksinagaliman (B),motif batik Bouraq (C), dan motif batik Daun Kluwih (D). 


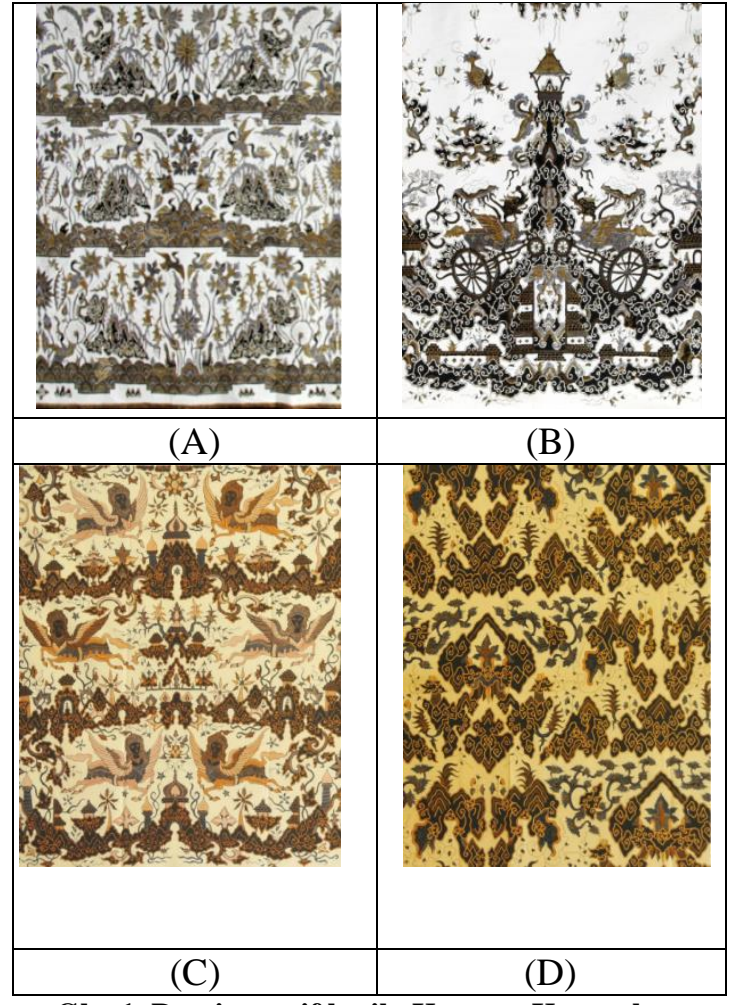

Gbr 1. Desain motif batik Keraton Kasepuhan dan batik Keraton Kanoman Cirebon Sumber : Kudya, 2014

Batik Keraton Kasepuhan memiliki unsur pembeda dengan Batik Keraton-keraton Cirebon yang lainnya, di antaranya pada : ragam hias singa barong adalah salah satu yang menjadi ciri khasnya. Dari sisi corak batik keraton-keraton lainnya memiliki kesamaan dengan batik-batik yang terdapat di Keraton Kasepuhan, hal ini tidak menutup kemungkinan dikarenakan asal sumbernya yang berasal dari budaya yang sama, yang telah diturunkan oleh Pangeran Cakrabuwana selaku sesepuh dan pendiri Kasultanan Cirebon. Corak Batik Cirebon dengan warna dasar kuning-gading atau kuning muda, atau kadangkala warna dasar broken white, warna tersebut dihasilkan akibat dari pross pelorodan . Akibat dari proses melorod ini terkadang mengakibatkan warna dasar kain menjadi warna putihnya tidak bersih. Ciri lain dari batik keraton ini biasanya memiliki latar atau dasar dengan banyak area kosong sehingga nampak lega (luas) dan bentuk gambar (outline) yang tipis tidak terputus (mrawit) dengan warna yang lebih tua dibandingkan dengan warna dasar kainnya. Kekuatan inilah yang membedakan Batik Keraton Cirebon dengan batik-batik yang dihasilkan oleh daerah lainnya. (Komar, 2016).

\section{c. Batik sebagai Ruang Identitas dan Perilaku Masyarakat Cirebon}

Di dalam Selo Soemardjan (1976), tokoh antropologi berpendapat bahwa kebudayaan membatik merupakan bagian dari hasil cipta, rasa dan karsa masyarakat. Karya masyarakat menghasilkan teknologi dan kebudayaan kebendaan atau kebudayaan jasmaniah (material kultur). Diperlukan oleh manusia untuk menguasai alam sekitarnya agar kekuatan serta hasilnya dapat diabadikan untuk keperluan masyarakat.(Soemardjan, Soekanto, 1976). Sedangkan di dalam Rokhani (2017), berpendapat yang berkaitan dengan produk kesenian dan identitas kultural budaya, bahwa batik Cirebon yang disinyalir sejak abad 15 hingga kini memberikan identitas kultural budaya masyarakat Cirebon, khususnya yang berada di sekitar Kabupaten Cirebon kini telah memiliki kekuatan yang menjelma sebagai kekuatan ruang identitas kria dan seni batik yang dapat mewarnai khazanah tradisi budaya batik Indonesia. Batik sebagai produk kesenian sekaligus menjadi atribut budaya yang mampu menjadi unsur pembangun identitas masyarakat Cirebon. Identitas Wong Cerbon melalui kesenian batik memunculkan konstruksi yang berbeda terkait dengan tradisi budaya batik dengan keberadaan masyarakat Jawa Barat lainnya.(Rokhani et al., 2017).

Bukti bahwa batik Cirebon telah menjelma menjadi ruang identitas dapat dilihat dari fungsi batik yang berubah dari awalnya sebagai kain-kain penutup baian anggota tubuh berubah fungsi sebagai bagian dari elemen estitis dan citra sekaligus penanda kekuatan identitas daerah Cirebon dengan kekuatan beragam variasi corak dan motif batiknya. Variasi ragam hias batik Cirebon telah sering mewarnai pameran-pameran batik nasonal di Jakarta dengan elegan dan diberi kesempatan dengan booth khusus yang mewah dan megah. Dengan sering disertakannya batik Cirebon dengan diciptakan ruang pamer yang menyertakan identitas budaya keraton Cirebon seperti bentuk Gapura Lawang Megamendung 
Keraton Kasepuhan, memberikan citra positif bagi identitas ruang seni dan b udaya masyarakat Cirebon ditengah hegemoni budaya modern di tengah ibukota Indonesia di Jakarta. Dengan semakin seringnya para seniman Cirebon, perajin-perajin batik Cirebon mengikuti ajang pameran dagang dan pameran seni budaya, dengan menghadirkan bentuk sajian seni tari, musik serta produk-produk batik dengan berbagai corak, kualitas dan kapasitasnya sebagai perajin batik tradisional semakin mewarnai kekuatan. Seperti pada Pameran Gelar Batik Nusantara yang diadakan di Jakarta, tepatnya di gedung Jakarta Convention Center pada tahun 2015. Pameran tersebut menampilkan batik- batik karya para pengrajin nusantara, dimana motif batik Keraton Cirebon menjadi salah satu karya yang dipamerkan, seperti pada gambar 2 (Gbr.2).

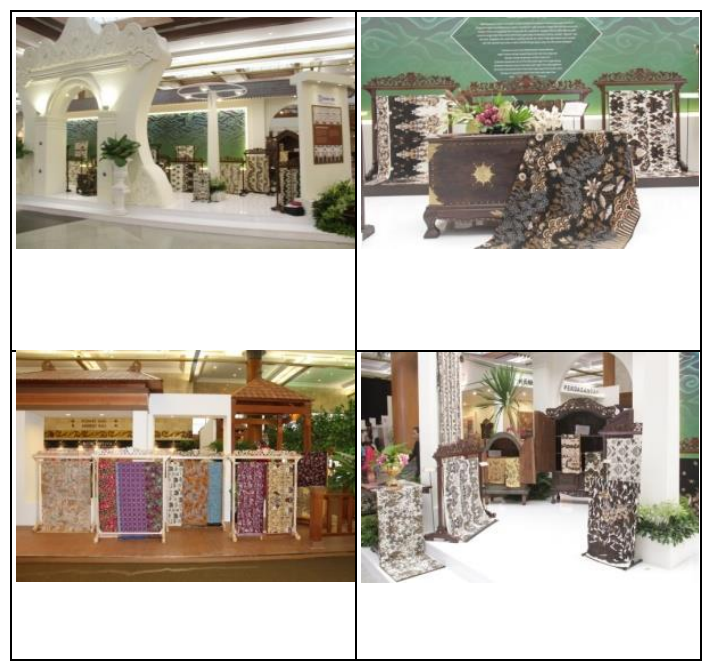

Gbr 2. Batik Cirebon pada Pameran Gelar Batik Nusantara 2015

Sumber : Kudya, 2015

Setelah menjelaskan latar belakang yang telah disebutkan di atas, maka penulis dapat merumuskan beberapa permasalahan sebagai berikut :

a. Bagaimana upaya pemerintah Kabupaten Cirebon melakukan identifikasi keberadaanbatik Cirebon sebagai kekuatan ruang identitas batik Cirebon yang dapat mendorong kekuatan ekonomi dan budaya? b. Bagaimana memberikan perlindungan terhadap Batik Cirebon yang merupakan sumber strategis Indikasi Geografis?

\section{METODE PENELITIAN}

Penelitian ini menggabungkan metodedeskriptif analitis dan metode etnografi, yang bertujuan untuk mendeskripsikan gambaran secara lengkap, sistematis dan menyeluruh mengenai hubungan antara objek yang diteliti dengan data-data pendukung yang akan dijadikan rumusan. (Irianto, 2017). Metode etnografi digunakan dikarenakan berkaitan dengan mempelajari masalah kultural, menyajikan cara pandang kehidupan orang di dalam objek. (Spradley, 1979). Masalah aktivitas dan makna ruang menjadi pembahasan yang focus dengan metode ini, yaitu melalui wawancara mendalam (indepth interview) melalui tokoh yang kompeten.

Studi kepustakaan digunakan sebagai data sekunder, untuk mengkomparasi antara teori dan bukti-bukti yang didapatkan di lapangan. Melalui studi kepustakaan ini diharapkan akan mendapatkan data tambahan dengan cara mempelajari bukubuku, artikel dan bahan bacaan dari media URL (Uniform Resource Locator) serta sumber rujukan lainnya yang berkaitan dan berhubungan dengan penelitian ini.Dalam penelitian ini hanya dilakukan terhadap mereka yang terpilih menjadi responden. Penentuan responden ini dilakukan secara purposive sampling yaitu didasarkan atas ciri-ciri tertentu yang dipandang mempunyai keterikatan yang erat dengan ciri-ciri populasi yang dimaksudkan dalam penelitian ini. (Saryono, 2013).

Berdasarkan atas kebutuhan tersebut, maka yang dijadikan sumber bahan penelitian ini adalah sebagai berikut: Sultan Sepuh IX PRA H. Arief Natadiningrat SE, Budayawan Cirebon drh. H. Bambang Irianto, Erwin Ibrahim Ir., Sekretaris Asosiasi Perajin dan Pengusaha Batik Indonesia (APPBI), H. Abdul Qodir S.Ag perajin batik Cirebon, Katura perajin batik tradisional Cirebon,dengan menggunakan metode analisa data diskriptif Analitis.

\section{Kerangka Teori}

Sebelum melakukan pembahasan yang berkaitan dengan judul penelitian tersebut di atas, maka sebaiknya perlu dikenalkan beberapa istilah yang berkaitan dengan 
penelitian tersebut. Kata identifikasi merupakan salah satu istilah yang diambil dalam penelitian ini. Seperti apa yang disampaikan oleh Chaplin dalam kamus lengkap psikologi bahwa identifikasi merupakan proses pendekatan yang utuh serta meletakkan obyek atau individu dalam golongan tertentu yang memiliki karaktristik untuk dipahami. (Geller, 2016).

Indikasi Geografis (IG) dapat diartikan satu jenis atau bagian yang tidak dapat dipisahkan dari produk hukum HKI selain dari Hak Cipta, Paten, Informasi Rahasia/Rahasia Dagang dan beberapa jenis produk HKI lainnya.Menurut Miranda pakar IG dan dosen Hukum UNPAD menyampaikan IG merupakan sebuah nama dagang yang dapat dikaitkan secara penuh, dapat digunakan sebagai penanda pada kemasan produk tertentu dan berfungsi sebagai penunjuk asal tempat produk tersebut. Asal tempat menandakan dimana kualitas dari produk tersebut amat dipengaruhi oleh kondisi geografis wilayah tersebut, dengan demikian menjadikan produk itu bernilai unik, khususnya konsumen yang mengenal reputasi tempat yang menghasikan suatu produk tersebut.(Ayu, 2017).

Ruang menjadi bagian tak terpisahkan dalam aktivitas sehari-hari. Ruang terbentuk dari pengalaman yang secara langsung dirasakan dalam bentuk tiga demensional dengan bantuan indra penglihat (Tuan, 2010:12). Pengalaman terkumpul menjadi ingatan dan cara tertentu untuk merasakan ruang. Karakter manusia dan kebudayaan menbentuk pola aktivitas dan pemaknaan sebuah ruang. Karakter yang kuat dari budaya akan menciptakan ruang dengan identitas khas sehingga dapat dirasakan sebuah place. (Khairunnisa, 2014).

Di dalam Sarwono menyebutkanidentitas merupakan hal yang fundamental pada setiap interaksi sosial dan selanjutnya menentukan bentuk interaksi sosialnya. Dalam bidang sosiologi, konsep identitas mengacu kepada struktur keanggotaan kelompok, seperti peranan sosial, kategori dan ciri yang dapat menunjukkan seorang individu dalam suatu kelompok tertentu. Seseorang yang beridentitas sama mempunyai persamaan kebudayaan, institusi-institusi dasar seperti agama, bahasa, organisasi sosial dan politik. Secara umum, konsep identitas mengacu kepada the self, yaitu menerangkan apa dan siapa seseorang itu. Hal ini sebagaimana yang didefinisikan oleh Hogg dan Abrams. (Eriyanti, 2006).

Dari uraian teori tersebut di atas dapat diartikan bahwa ruang identitas batik Cirebon menjelma dengan berjalannya waktu semakin dikenalnya ragam hias batik Cirebon yang dulu dikenal hanya dengan motif batik Megamendung, kini bertambah dengan beraneka ragam hias dan corak yang semakin mewarnai kancah pemasaran batik-batik tradisional Indonesia. Dengan semakin kuat gaung dari batik Cirebonan, mengubah perilaku sebagian masyarakatnya lebih mencintai pemakaian, penggunaan dan tumbuh rasa cinta dengan citra batik Cirebon. Kemaslahatan batik Cirebon semakin dirasakan khususnya bagi perajin batik dan masyarakat Cirebon pada khususnya ditandai dari semakin banyak lahirnya perajin-perajin batik baru, serta semakin banyak konsumen yang mencari, mengoleksi batik-batik Cirebon di saat mendatangi pameran-pameran batik tingkat nasional di Jakarta.

\section{PEMBAHASAN}

\section{a. Data hasil identifikasi kekuatan masyarakat pembatik Cirebon}

Akurasi data kependudukan Kabupaten Cirebon berdasarkan Badan Pusat Statistik Kabupaten Cirebon merupakan dasar bagi penulis untuk mendapatkan data yang akurasinya dapat dipertanggungjawabkan. Penulis khususnya akan mencari data yang berhubungan dengan data penduduk di daerah-daerah yang menghasilkan kerajinan batik dalam mendukung potensi kerajinan batik Kabupaten Cirebon. Daerah penghasil kerajinan batik Cirebon, difokuskan pada daerah kecamatan Plered dan Kecamatan Ciwaringin Kabupaten Cirebon.

Penduduk Kecamatan Plered Kabupaten Cirebon berdasarkan Badan Pusat Statistik Kabupaten Cirebon berdasarkan proyeksi 
penduduk tahun 2018 sebanyak 55.303 jiwa yang terdiri atas 28.059 jiwa penduduk laki-laki dan 27.244 jiwa penduduk perempuan. Jumlah penduduk berumur 15 tahun keatas yang bekerja menurut lapangan usaha pertanian pada tahun 2018 terdiri sebanyak 1.732 jiwa laki-laki, sedangkan di lapangan kerja jasa-jasa terdiri sebanyak 11.124 jiwa laki-laki. Para pencari kerja yang terdaftar di Kecamatan Plered terbanyak berada di Desa/Kelurahan Tegalsari dengan total keseluruhan 8.272, sedangkan pencari kerja yang paling sedikit berada di desa/Kelurahan Trusmi Wetan dengan total keseluruhan 2.489 jiwa.

Penduduk kecamatan Ciwaringin berdasarkan perkiraan capaian penduduk tahun 2018 sebanyak 36.422 jiwa yang terdiri atas 18.714 jiwa penduduk laki-laki dan 17.708 jiwa penduduk perempuan. (Badan Pusat Statistik Kabupaten Cirebon, 2019).

\section{b. Data Perajin Batik Cirebon Jawa Barat Indonesia}

Data perajin batik yang berada di 2 (dua) wilayah Kecamatan Plered dan Kecamatan Ciwaringin berdasarkan data yang didapat dari Yayasan Batik Jawa Barat (YBJB) pada tahun 2018 sebanyak 1.625 jiwa. Perajin batik terbanyak berada di Kecamatan Plered sebanyak 1.405 jiwa yang berasal dari Desa Panembahan, Desa Trusmi Wetan, Desa Trusmi Kulon, Desa Sarabau, Desa Gamel, Desa Wotgali dan Desa Kaliwulu. Adapun pusat dari para pengusahanya terdapat di Desa Trusmi Kulon dan Desa Panembahan.Sedangkan jumlah perajin batik yang berada di Kecamatan Ciwaringin sejumlah 220 tidak sebanyak yang berada di Kecamatan Plered.Dari kedua kecamatan yang berada di Kabupaten Cirebon, menempati $54 \%$ dari total jumlah perajin batik yang berada di Jawa Barat. Sedangkan bila di komparasi dengan seluruh jumlah perajin batik dari seluruh Indonesia yang berjumlah 131.565 orang, maka menempati jumlah $1.23 \%$ dari total perajin batik di seluruh Indonesia, sedangkan perajin batik Jawa Barat menempati urutan terbesar ke 3, dibawah dari Propinsi Jawa Tengah dan Jawa Timur berdasarkan data yang didapatkan dari
Asosiasi Perajin dan Pengusaha Batik Indonesia (APPBI).

Dengan demikian wilayah Cirebon dengan potensi kekuatan motif batik yang dimilikinya dapat merepresentasikan kekuatan ruang kriya batik tradisional Jawa Barat sebagai pelengkap dari mozaik batik Indonesia.

\section{c. Aneka Jenis Produksi Batik Cirebon}

Kain Batik yang diproduksi oleh perajin batik tradisional khususnya di Kabupaten Cirebon dapat digolongkan menjadi batik dengan kualitas tulis dan kualitas batik cap, atau kombinasi dari kedua teknik tersebut.Adapun jenis produksinya yaitu terdiri dari kain panjang (jarik), kain sarung selendang, bahan blouse, bahan kemeja, selendang, kain elemen estetis, scarf serta dasi batik. Dari komposisi jenis produksi yang paling banyak di produksi dan berdasarkan urutan tertinggi diantaranya 1) bahan blouse, 2) bahan kemeja, 3) kain panjang, 4) sarung selendang, dan 5) scarf atau kerudung. Jumlah produksi jenis batik cap bisa mencapai 3,5 juta potong/tahun dan 22 ribu potong/tahun untuk batik dengan kualitas yang baik.

Kain-kain batik yang diproduksi oleh sebagin besar masyarakat Kabupaten Cirebon tidak hanya dikonsumsi oleh masyarakat Jawa Barat semata. Namun sebagian besar produsen batik yang berada di Kabupaten Cirebon memproduksi pesanan-pesanan kain batik dengan corak dan motif dari luar propinsi Jawa Barat. Sebagian produksi kain-kain batik yang dihasilkan dari Kabupaten Cirebon dan sekitarnya merupakan pesanan dari daerah Sumatra (Palembang, Jambi, Lampung dan Aceh)hal ini menunjukkan dan membuktikan bahwa kekuatan ruang identitas batik-batik tradisional dari wilayah Cirebon Jawa Barat mampu menciptakan ruang-ruang identitas batik tradisional di luar dari wilayah Cirebon itu sendiri. Dengan demikian kekuatan hasil dari kolaborasi antara corak dan motif hasil kebudayaan dari luar wilayah Cirebon yang dipadukan dengan kekuatan ruang identitas perajin batik tradisional Cirebon tersebut menunjukkan potensi untuk ruang identitas geografis Indonesia. 
Produksi kain batik Cirebon kini menjelma tidak hanya sebagai kain yang dijadikan sebagai produk fashion, namun memiliki varian sebagai produk elemen estetis yang dapat dimaknai sebagai pengembangan dari fungsi kain batik itu sendiri. Dengan dimanfaatkan kain-kain batik Cirebon untuk pengisi ruang-ruang publik dan ruang khusus seperti ruang tamu, ruang receptionis, ruang tunggu, ruang meeting dan lainnya, akan memberikan identitas dan kekuatan baru bagi citra positif batik Cirebon. Seperti pada Gambar 3 (Gbr.3), motif-motif batik Cirebon dapat dijadikan sebagai elemen dekoratif pada ruangan, diantaranya motif Tambal (A), motif Piring Lampad (B), motif Sawat Riwe (C) Motif Buketan Latar Galaran (D).

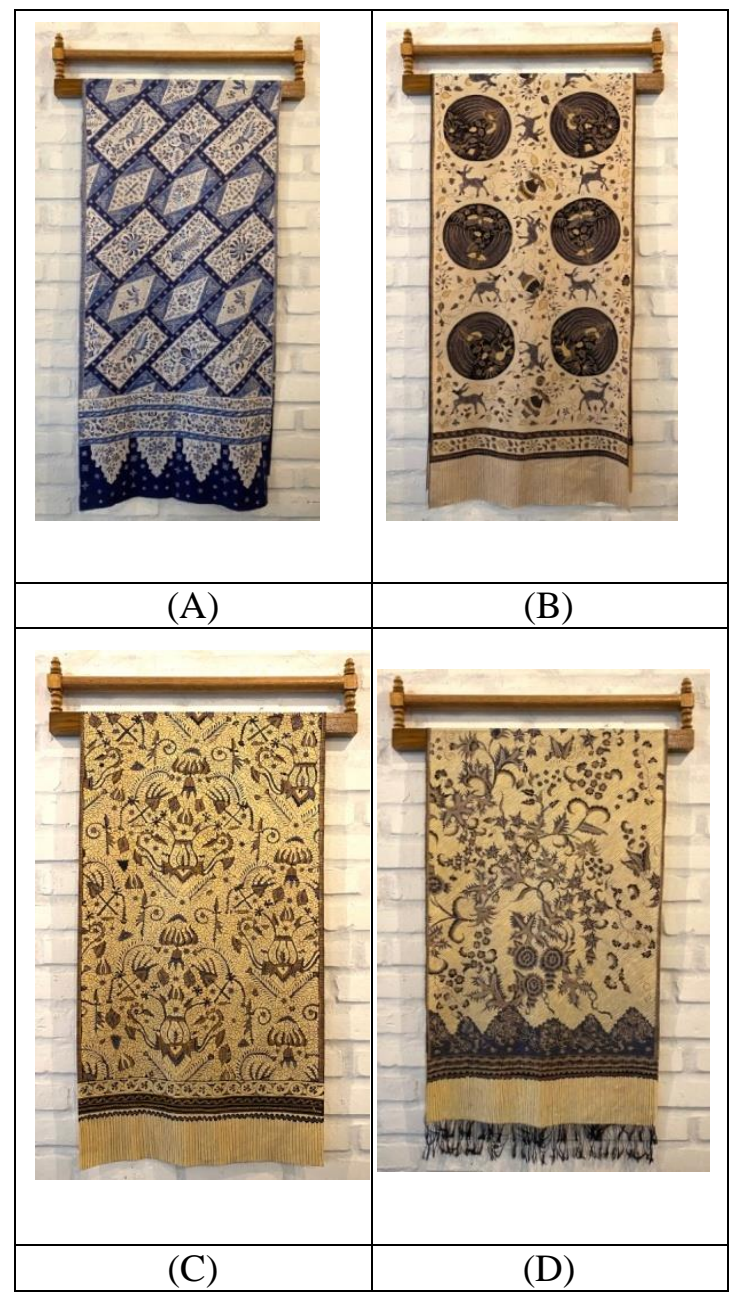

Gbr 3. Batik Cirebon sebagai Elemen Estetis Ruangan

Sumber : Kudya, 2015

\section{d. Batik Cirebon memiliki potensi Indikasi Geografis yang perlu di daftarkan}

Di dalam Purba (2002) disampaikan bahwa hampir di seluruh dunia internasional mulai tertarik dengan perlunya perlindungan Indikasi geografis (IG), dengan demikian dibentuklah beberapa perjanjian bilateral dan multilateral untuk melindungi produkproduk unggulan yang dimiliki oleh beberapa negara yang meratifikasi perjanjian internasional tersebut. Bentuk perlindungan hukum internasional tentang IG diantaranya adalah "Paris Convention for the Protection of Industrial Property tahun 1983 dan Madrid Agreement tahun 1891.". Lebih lanjut disampaikan oleh Achmad Zen Purba (2002) dalam buku "International Regulation on Geopraphical Indications, Genetic Resources and Traditional Knowledge" menyebutkan bentuk perjanjian internasional tersebut telah menetapkan perihal "Indication of Source as an indication referring to a country or a place in that country, as being the country or place of origin of a product."(Purba, 2002).Sedangkan pada perjanjian TRIPs Agreement article 22 juga mengatur tentang Indikasi Geografis yang menyebutkan bahwa:

"Geographical indications are for the purposes of this agreement, indications which indentify a good as originating in the territory of a member, or a region or locality in that territory, where a given quality, reputation or other characteristics of the good is essentially attributable to its geographical origin".

Adapun menurut Saidin dalam buku Aspek Hukum dan Kekayaan Intelektual yang disampaikan oleh Kusumadara (2011), menyebutkan bahwa perjanjian TRIPs memberikan definisi Indikasi Geografis sebagai tanda dapat memberikan identifikasi suatu wilayah tertentu terhadap asal barang yang bersangkutan yang sangat dipengaruhi oleh faktor geografis serta memiliki reputasi, keunggulan dan pastinya memiliki jaminan karakteristik tertentu yang dijamin dengan faktor yuridis.(Kusumadara, 2011). 
Di Indonesia, IG telah dilindungi hukum tetap yang telah disesuaikan dengan peraturan internasional walaupun secara khusus tidak wajib atau mesti sama. Didalam Undang-undang dan hukum formal republik Indonesia, perihalIndikasi Geografis diatur di dalam UUnomor 15 Tahun 2001 tentang Merek pada Pasal 56 ayat 1 yang menyebutkan: "Indikasi geografis dilindungi sebagai suatu tanda yang menunjukkan daerah asal suatu barang, yang karena faktor lingkungan geografis termasuk faktor alam, faktor manusia, atau kombinasi dari kedua faktor tersebut sehingga memberikan ciri dan kualitas tertentu pada barang yang dihasilkan."

Pemerintah RI juga mengeluarkan Peraturan Pemerintah (PP) Nomor 51 Tahun 2007 yang mengatur secara teknis tentang Indikasi Geografis.Kelanjutan dari Permen yang terbaru diterbitkannyaPermen Hukum dan Ham Republik Indonesia nomor 12 tahun 2019 tentang Indikasi Geografis (IG). Potensi produk-produk IG yang dimiliki oleh bangsa Indonesia, memiliki peluang yang sangat besar untuk bersanding di dunia internasional, namun hingga akhir tahun 2019, terdapat 68 potensi Indikasi Geografis yang telah berhasil di daftarkan di Kemenkumham dari seluruh Indonesia, diantara jumlah tersebut 8 merupakan IG dari Jawa Barat. Undang-undang Hak Cipta memberikan perlindungan terhadap produk batik yang merupakan bagian dari Pengetahuan Tradisional dan Ekspresi Budaya Tradisional (PT-EBT).Dalam perundangan Hak Kekayaan Indonesia (HKI), produk batik. tradisional juga dimasukkan dalam Warisan Budaya Tak Benda yang juga turut dilindungi secara hukum. Adapun produk hukum dari HKI ini diantaranya adalah pelindungan tentang Indikasi Geografis.

Tradisi batik tradisional Jawa Barat yang kini memiliki potensi untuk di daftarkan IG-nya tidak hanya batik merawit Kabupaten Cirebon. Namun masih terdapat satu lagi yang memiliki potensi untuk di daftarkan IG-nya yaitu kerajinan batik khas "complongan" dari daerah Kabupaten Indramayu. Teknik complongan inipun tidak dimiliki oleh daerah penghasil batik di Jawa Barat lainnya, juga tidak dimiliki keahlian khusus ini di daerah penghasil nusantara lainnya. Hal ini membuktikan bahwa potensi kerajinan batik tradisional Jawa Barat layak untuk mendapatkan sertifikasi IG dari Direktorat HKI, sebagai bentuk pengakuan yang pada akhirnya akan memberikan nilai-nilai sebagaimana layaknya produk-produk yang tyelah mendapatkan sertifikasi IG-nya. Dengan dumikian apakah kita harus menunguggu waktu yang cukup lama lagi, sementara persaingan bisnis tidak dapat dihindari, semakin hari akan bermunculan produkproduk unggulan yang dapat membawa citra positif dan nilai ekonomi bagi wilayah-wilayah tertentu yang sigap dalam memanfaatkan potensi daerahnya masingmasing.(Aklimawati et al., 2014).

\section{e. Korelasi kekuatan identitas ruang batik Cirebon sebagai nilai budaya dengan nilai ekonomi.}

Sebelum kita membahas perihal hubungan korelasi antara nilai budaya dan nilai ekonomi sebaiknya kita perlu mengenali terlebih dahulu apa yang dimaksud dengan nilai budaya. Koentjaraningrat telah menyampaikan dengan jelas bahwa didalam budaya terdapat nilai-nilai serta konsepsi-konsepsi yang merupakan bagian yang tidak terpisahkan dari alam fikiran masyarakat tertentu yang perlu mendapatkan perlindungan.(Prof. Dr. Koentjaraningrat, 2007).

Bila kita cermati dengan lebih detil dan apa yang telah kita rasakan bersama, kerajinan batik tradisional merupakan bagian dari nilai-nilai alam fikiran masyarakat tertentu yang hidup dalam hal-hal yang dinyatakan amat mulia bagi sebagian golongan tertentu. Beberapa motif batik tradisional yang dihasilkan oleh para leluhur, hingga kini menempati marwah tinggi yang tidak bisa ditandingi oleh produk budaya manusia yang lainnya.Di dalam motif batik tradisional memiliki nilai-nilai filosofi dan makna luhur budaya yang senantiasa dianggap dapat memberikan nilai-nilai terhormat di tengah masyarakat dan kelaskelas tertentu di masyarakat.Nilai-nilai tersebut secara tidak langsung membentuk dan melahirkan ruang-ruang identitas. Jika 
pemikiran Yi Fu Tuan (2010) tentang ruang dikembangkan, maka dapat diuraikan bahwa nilai-nilai yang diperoleh dari batik tradisional berasal dari aktivitas sehari-hari dalam berkegiatan serta mengalami membatik, melihat batik dan memaknainya.

Sedangkan yang diartikan sebagai nilai ekonomi lebih kurangnya nilai yang mendasari perbuatan seseorang atau sekelompok orang atas dasar pertimbangan ada tidaknyakeuntungan finansial sebagai akibat dari perbuatannya itu.(Hanley \& Perrings, 2019).Kelompok-kelompok perajin batik di berbagai daerah telah membuktikan keunggulan dari segi teknik maupun dari metode dalam memproduksi batik-batiknya dengan beraneka keunggulan yang tidak dimiliki oleh wilayah lain. Hal ini yang mendorong diperlukannya upaya pemerintah daerah untuk segera melakukan upaya identifikasi tentang hal tersebut. Pada suatu daerah tertentu penghasil batik didapatkan teknik khusus dan unik yang sama sekali tidak dapat dilakukan oleh daerah penghasil batik lainnya. Keunggulan yang dimiliki oleh daerah tersebut bukan saja akan meningkatkan reputuasi dan kekhasan produknya, namun bila dikaitkan dengan nilai finansial, maka akan mendatangkan keuntungan yang sangat tinggi, tentunya bila IG yang didapatkannya di fungsikan secara optimal.

Dengan demikian dapat memberikan asumsi bahwa nilai-nilai budaya merupakan buah dari sebuah konsepsi manusia yang melahirkan sebuah produk budaya berupa kerajinan tangan seperti halnya kerajinan batik tradisionalapabila dilakukan dengan pertimbangandari sisi finansial akan mendatangkan keuntungan secara ekonomi khususnya bagi masyarakat yang terlibat baik secara langsung maupun memberikan kontribusi dalam berlangsungnya proses budaya tersebut. Sementara pelindungan secara hukum dari proses budaya yang turun temurun berjalan di suatu wilayah atau geografis tertentu, dengan memiliki reputasi, kualitas dan karakteristik akan mendapatkan pelindungan dari Indikasi Geografis.(Ayu, 2017).
Melihat kuatnya korelasi antara nilai-nilai budaya masyarakat Cirebon melalui identitas ruang batik Cirebon yang telah memiliki citra positif dikaitkan dengan nilai-nilai ekonomi yang dihasilkannya, kini sudah menjadi keharusan bagi pemerintah Jawa Barat untuk segera melakukan identifikasi dan pendaftaran IG dengan mengikuti prosedur-prosedur yang telah ditentukan oleh Undang-Undang HKI di Kemenrian Hukum dan Ham.

\section{SIMPULAN}

a. Berdasarkan data di lapangan ditemukan bahwa di Kabupaten Cirebon terdapat sentra kerajinan batik tradisional yang memiliki kekuatan ruang idengtitas yang sangat potensial sebagai wahana pelestarian budaya masyarakat Cirebon sebagai bagian dari pelestarian batik Indonesia, bahkan ruang identgitas tersebut telah mampu meluas ke daerah lain. Potensi kekuatan tersebut ditunjukkan dengan didapatnya reputasi, kualitas, karakteristik dan faktor lingkungan/geografis yang dimiliki sebagai potensi dari pendaftaran Indikasi Geografis. b. Data sejarah, data jumlah perajin, data ragam hias batik Cirebon, kelompok perajin batik yang telah diwadahi dalam asosiasi merupakan data penunjang yang sudah dapat diidentifikasi dan dikompilasi untuk diwujudkan menjadi dokumen pendaftaran Indikasi Geografis yang sudah lengkap. Berikutnya data kondisi di lapangan yang terdapat di wilayah sentra kerajinan batik Cirebon dijadikan lampiran yang dapat mendukung didaftarkannya IG batik Cirebon.

c. Kerajinan batik tradisional Cirebon dengan segala macam potensi yang telah disebuatkan di atas, maka sangat layak untuk mendapatkan pengakuan dan terdaftar sebagai IG produk kerajinan batik yang memiliki semua data yang butuhkan untuk persyaratan pendaftaran IG di Kemenkumham.

\section{Saran}

a. Dibutuhkan data yang lengkap dan komprehensif tentang peta kekuatan dari kerajinan batik Kabupaten Cirebon 
yangterdapat di wilayah Kecamatan Plered meliputi daerah desa Trusmi Wetan, desa Trusmi Kulon, desa Kaliwulu, desa Wotgali, desa Gamel, desa Sarabau, desa Panembahan.

b. Kekuatan dapa perajin batik yang dimaksud diantaranya adalah jumlah perajin batik yang aktif berikut dengan kekuatan modal, jumlah perajin batiknya, jumlah produksi yang dihasilkannya, jumlah perajin pembuat cap batik, perajin pembuat canting tulis, jumlah tukang gambar (batik designer), pedagang penyedia bahan-bahan batik.

c. Perlu identifikasi teknik membatiknya, jumlah ragam hias batik daerah yang khas tradisional, jumlah ragam hias diluar batik tradisional dari luar Pulau Jawa yangdikerjakan oleh perajin batik Cirebon.

d. Perlu diidentifikasi segala hal yang berkaitan dengan permasalahan yang dihadapi oleh para perajin batik Cirebon.

\section{DAFTAR PUSTAKA}

[1] Aklimawati, L., Yusianto, \& Mawardi, S. (2014). Karakteristik Mutu dan Agribisnis Kopi Robusta di Lereng Gunung Tambora, Sumbawa. Pelita Perkebunan.

[2] Anas, B., Hasanudin, Panggabean, R., dan Sunarya, Y. (1997) : Indonesia Indah Buku ke-8, Batik, Jakarta : Yayasan Harapan Kita - BP3 Taman Mini Indonesia Indah, Perum Percetakan Negara RI, cetakan I, 14, 22.

[3] Ayu, M. R. (2017). SISTEM PERLINDUNGAN SUMBER DAYA BUDAYA TAK BENDA DI PALEMBANG, SUMATERA SELATAN, INDONESIA. Mimbar Hukum.

https://doi.org/10.22146/jmh.16671

[4] Chaplin, W. F. (1991). The Next Generation of Moderator Research in Personality Psychology. Journal of Personality. https://doi.org/10.1111/j.14676494.1991.tb00772.x
[5] Eriyanti, F. (2006). Dinamika posisi identitas etnis tionghoa dalam tinjauan teori identitas sosial. Demokrasi.

[6] Geller, E. S. (2016). The Psychology of Safety Handbook. In The Psychology of Safety Handbook. https://doi.org/10.1201/978142003256 7

[7] Hanley, N., \& Perrings, C. (2019). The Economic Value of Biodiversity. Annual Review of Resource Economics.

https://doi.org/10.1146/annurevresource-100518-093946

[8] Hogg, Michael and Dominic Abrams. 1988. Social Identifications: A Social Psychology of Intergroup Relations and Group Processes. London: Routledge.

[9] Irianto, S. (2017). METODE PENELITIAN KUALITATIF DALAM METODOLOGI PENELITIAN ILMU HUKUM. Jurnal Hukum \& Pembangunan. https://doi.org/10.21143/jhp.vol32.no2 .1339

[10] Khairunnisa, M. (2014). KOSMOLOGI RUANG ADAT SEBAGAI IDENTITAS PEMUKIMAN KAMPUNG NAGA, TASIKMALAYA - JAWA BARAT. Teknik. https://doi.org/10.14710/teknik.v35i1. 7040

[11] Kudiya, K., Sabana, S., \& Sachari, A. (2014). Revitalisasi Ragam Hias Batik Keraton Cirebon dalam Desain Baru Kreatif. Panggung. https://doi.org/10.26742/panggung.v2 $4 \mathrm{i} 2.116$

[12] Kudiya, K., (2016). Disertasi S3 FSRD-ITB " REVITALISASI BATIK LAMAKERATON-KERATON CIREBON DENGAN RAGAM HIAS TAMAN TELAGA TERATAI SEBAGAI WUJUD REFLEKSI INTEGRASI BUDAYA.

[13] Kuhr, D.-R. G. (2012). Iwan Tirta (1960-2000) - The commodification of Batik: Brokering past as present \& the re-imagination of "Indonesian personality." ProQuest Dissertations and Theses. https://doi.org/10.1017/CBO97811074 15324.004 
[14] Kusumadara,

A. (2011).

PEMELIHARAAN

DAN

PELESTARIAN PENGETAHUAN

TRADISIONAL DAN EKSPRESI

BUDAYA

TRADISIONAL

INDONESIA: PERLINDUNGAN

HAK KEKAYAAN INTELEKTUAL

DAN NON-HAK KEKAYAAN

INTELEKTUAL. JURNAL HUKUM

IUS QUIA IUSTUM.

https://doi.org/10.20885/iustum.vol18. iss1.art2

[15] Poerwadarminta. (2005). Kamus Umum Bahasa Indonesia. Jakarta: Balai Pustaka. Muhibbin Syah. https://doi.org/10.1016/j.bbapap.2013. 06.007

[16] Prof. Dr. Koentjaraningrat. (2007). "Manusia dan Kebudayaan Di Indonesia." Djambatan. https://doi.org/10.1016/s00448486(97)00050-1

[17] Purba, A. Z. U. (2002). PETA MUTAKHIR HAK KEKAYAAN INTELEKTUAL INDONESIA. Jurnal Hukum \& Pembangunan. https://doi.org/10.21143/jhp.vol32.no1 .1319

[18] Rokhani, U., Salam, A., \& RochaniAdi, I. (2017). Konstruksi Identitas Tionghoa melalui Difusi Budaya Gambang Kromong: Studi Kasus Film Dikumenter Anak Naga Beranak Naga. Resital: Jurnal Seni Pertunjukan.

https://doi.org/10.24821/resital.v16i3. 1679

[19] Saryono. (2013). Metodelogi Penelitian Kualitatif dan Kuantitatif. In Medical Book. https://doi.org/10.1007/978-1-49392572-8_13

[20] Sarwono, S.W. 1999. Psikologi Sosial: Individu dan Teori-Teori Psikologi Sosial. Jakarta: Balai Pustaka.

[21] Setiawan, I. (2010). BATIK GARUT: Studi Tentang Sistem Produksi dan Pemasaran. Patanjala: Jurnal Penelitian Sejarah Dan Budaya. https://doi.org/10.30959/patanjala.v2i3 .236

[22] Soemardjan, Soekanto, S. S. (1976). Kebudayaan dan Hukum. Jurnal Hukum \& Pembangunan. https://doi.org/10.21143/jhp.vol6.no4. 624

[23] Spradley, J. (1979). Step 4: Asking Descriptive Questions. The Ethnographic Interview. https://doi.org/10.1017/CBO97811074 15324.004

[24] Suyani, S. (2013). PENGARUH BUDAYA ASING TERHADAP PERKEMBANGAN BATIK PEKALONGAN. CORAK. https://doi.org/10.24821/corak.v2i1.23 30

[25] Tuan.Y. (2010). Space and Place: The Perspective of Experience. London: University of Minnosota Perss.

[26] Yan, O.:, \& Sunarya, Y. (2010). BATIK PRIANGAN MODERN DALAM KONSTELASI ESTETIK DAN IDENTITAS. Desember Terbitan Asosiasi Pendidik Seni Indonesia.

\section{Website}

[1] http://disbun.jabarprov.go.id/post/view 1375-id-disbun-jabar-kembalimenggali-potensi-indikasi-geografiskomoditas-perkebunan

\section{Peraturan Perundang-undangan}

[1] Peraturan Menteri Hukum dan HAM Republik Indonesia No. 12 tahun 2019 Tentang Indikasi Geografis.

[2] UU nomor 15 Tahun 2001 tentang Merek pada Pasal 56 ayat 1 .

[3] Peraturan Pemerintah (PP) Nomor 51 Tahun 2007 yang mengatur secara teknis tentang Indikasi Geografis.

[4] Undang Undang No. 5 Tahun 2017 Pemajuan Kebudayaan

[5] Peraturan Menteri No. 106 Tahun 2013 - Warisan Budaya Tak Benda

[6] Peraturan Presiden Nomor 78 tahun 2007 tentang Pengesahan Convention for the Safeguarding of the Intangible Cultural Heritage (Konvensi untuk Perlindungan Warisan Budaya Takbenda) (Lembaran Negara Republik Indonesia 1997 Nomor 81; 